\title{
White Pepper Extract (Piper nigrum L.) as Antibacterial Agent for Streptococcus mutans In Vitro
}

\author{
Yona One Sidarta ${ }^{1}$, Nenny Prasetyaningrum ${ }^{2}$, Delvi Fitriani ${ }^{3}$, \\ Sumarno Reto Prawiro ${ }^{4}$ \\ ${ }^{I}$ (Student, Dentistry Program of Medical Faculty of Brawijaya University Malang Indonesia) \\ ${ }^{2}$ (Laboratory of Pathology Anatomy, Dentistry Program of Medical Faculty of Brawijaya University Malang \\ Indonesia) \\ ${ }^{3}$ (Laboratory of Dental Material, Dentistry Program of Medical Faculty of Brawijaya University Malang \\ Indonesia) \\ ${ }^{4}$ (Laboratory of Microbiology, Medical Doctor Program of Medical Faculty of Brawijaya University Malang \\ Indonesia)
}

\begin{abstract}
Streptococcus mutans is a gram-positive bacterium in oral cavity which metabolism produces acid as the common cause of dental caries (tooth decay). In order to prevent the growth or kill Streptococcus mutans, antibacterial agent is required. White pepper (Piper nigrum L.) is suspected to contain antibacterial substances such as alkaloid, phenol, tannin and coumarine. This research is conducted to prove the antibacterial effect of white pepper on growth activity of Streptococcus mutans in vitro. An experimental study using post test only control group design is carried out to Streptococcus mutans with tube dilution method and streaking on the Brain Heart agar plate. The treated groups are groups treated with white pepper extract with a range of concentration from 5\%; 7,5\%; $10 \% ; 12,5 \% ; 15 \% ; 17,5 \%$; and $20 \%$. The control groups consist of bacteria control and white pepper extract control. Result of the research indicates that Minimum Inhibitory Concentration (MIC) is found at concentration 10\% of the white pepper extract, where as the Minimum Bactericidal Concentration (MBC) is found at concentration 12,5\% of the extract. Data analysis is conducted with non parametric test of Kruskal Wallis. Kruskal Wallis test shows at least there is a difference of the number of colonies as the given concentration $(p<0,05)$. The correlation test of Spearman reveals a very strong reciprocal correlation between concentration of white pepper extract and the number of Streptococcus mutans colonies growth (Correlation, $r=-0,986 ; p<0,05$ ). The conclusion is white pepper extract has effect on the growth also as antibacterial agent for Streptococcus mutans in vitro, with MIC at concentration $10 \%$ and MBC at concentration 12,5\%. The higher concentration of white pepper extract, the lower growth rate of Streptococcus mutans.
\end{abstract}

Keywords - antibacterial, Streptococcus mutans, white pepper extract

\section{Introduction}

Streptococcus mutans is known as primary microorganism in formation of dental plaque and caries ${ }^{1}$. It is a gram positive bacterium, which is facultative anaerobe. Streptococcus mutans is able to produce acid causing acid environment which increases risk of dental caries ${ }^{2}$. The appearance of Streptococcus mutans in oral cavity is following the occurrence of caries within 6-24 months ${ }^{3}$.

Dental caries or tooth decay is a chronic endogenous infection caused by demineralization of enamel followed by dentin, as the impact of acid presence which produced by plaque bacteria through carbohydrate metabolism process ${ }^{4}$. Etiologies of caries are interaction between high sucrose diet, tooth as host, presence of microorganism, and also time of accumulation ${ }^{5}$. This disease is a worldwide spread and causing disturbance in human body such as chewing, food absorption also digestive function disturbance. Besides, it can be manifested as systemic disease, because decayed tooth is the site of focal infection. The National Health Survey Result on 2002 showed that the prevalence of tooth decay in Indonesia is 60\%, which means among ten Indonesian people, six of them suffer from tooth decay.

Preventive treatment against caries such as topical application of Fluor and fissure sealant, need the help of dentist $t^{5}$ also they are costly procedures. On the other hand, curative treatment by tooth filling is a fairly expensive procedure and still has the risk of secondary caries occurrence. So nowadays appear alternative treatment using herbal substance as preventive treatment against caries.

Herbal substances become alternative treatment preference regarding its ease to obtain and relatively low cost of money. Moreover the side effect is lower compared to the pharmaceutical drugs ${ }^{6}$. Pepper is one of herbal substance which is familiar and easy to find, but not so many research is conducted regarding its antibacterial effect against Streptococcus mutans. 
Some usage of pepper for example is to relieve pain, rheumatism, cold, flu, fever and muscle pain. Externally, it is used as rubefacient and local application to relax throat inflammation and some skin diseases. It's also been assessed the antimicrobial property ${ }^{7}$ and antimutagenic ${ }^{8}$. But the research on the antibacterial effect of white pepper is lacking.

Based on above statements, researcher is willing to prove antibacterial effect of white pepper extract (Piper nigrum L.) on growth activity of Streptococcus mutans. As the development of current technology, white pepper is later expected to be an alternative of herbal treatment against dental caries.

\section{Research Method}

\section{Identification}

The sample was Streptococcus mutans strain 2302-UNR, obtained from Laboratory of Microbiology, University of Airlangga Surabaya, East Java Province. The sample was identified by Gram staining, catalase test, carbohydrate fermentation test and optochin test.

The bacteria are calibrated to obtain bacteria liquid colonies containing $1 \times 10^{6} \mathrm{CFU} / \mathrm{ml}$.

\section{Extraction of White Pepper}

White pepper in granular form was grind into powder, and then it's extracted by maceration. Solvent used in the extraction was methanol $96 \%$. In this process, the whole or coarsely powdered crude white pepper is placed in a stoppered container with the solvent and allowed to stand at room temperature for a period of at least 3 days with frequent agitation until the soluble matter has dissolved. The mixture then is strained, the marc (the damp solid material) is pressed, and the combined liquids are clarified by filtration or decantation after standing ${ }^{12}$.

\section{Well Diffusion Method (Exploration)}

This method is a preliminary experiment which is a modification from disk diffusion method. It used $6 \mathrm{~mm}$ well filled with antibacterial extract. Wells are made by well perforator on the Brain Heart agar plate after fully streaked with Streptococcus mutans. After incubation, diameter of inhibition zone was measured to assess antibacterial activity of the extract.

\section{Tube Dilution Method}

It's used to obtain Minimum Inhibitory Concentration (MIC). Streptococcus mutans was added to each tube with different concentration of white pepper extract. After the tube of suspension's done, incubate all tubes for 24-48 hours at temperature $37^{\circ} \mathrm{C}$. Assess the result of incubation by looking at the tube blurriness. The MIC can be determined by then.

\section{Agar Streaking}

To obtain Minimum Bactericidal Concentration (MBC), the suspension of each tubes is streaked on the Brain Heart agar plate as many as $0,1 \mathrm{ml}$ (one ose). Then it's incubated in anaerobe environment for 24-48 hours at temperature $37^{\circ} \mathrm{C}$. Colony forming unit can be seen after incubation is done. The MBC can be determined by counting the colonies formed in agar plate.

\section{Statistical Analysis}

The result of bacteria colony counting is analyzed statistically by SPSS program (Statistical Product of Service Solution) for Windows version 19.0. Non-parametric statistic using Kruskal-Wallis test and Spearman test of correlation.

\section{Exploration / Preliminary Experiment}

\section{Result}

Preliminary experiment is conducted by well diffusion method using concentration of $100 \%, 50 \%$, $25 \%, 12,5 \%$ and $6,25 \%$. Inhibition zone was found $10-16 \mathrm{~mm}$ (including well diameter of $6 \mathrm{~mm}$ ). Obtained concentrations used in experiment which are 5\%,7,5\%,10\%, 12,5\%, 15\%, 17,5\% and $20 \%$. 


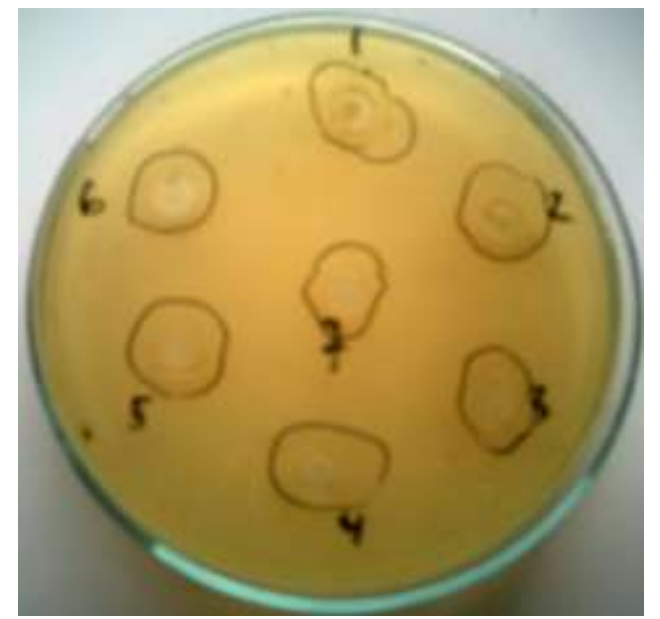

Figure 1. Well of white pepper extract on Braind Heart Plate after being streaked with Streptococcus mutans

Note: well number $1=100 \% ; 2=50 \% ; 3=25 \% ; 4=12,5 \%$; $5=6,25 \% ; 6=3,125 \% ; 7=1,5 \%$

\section{Tube Dilution}

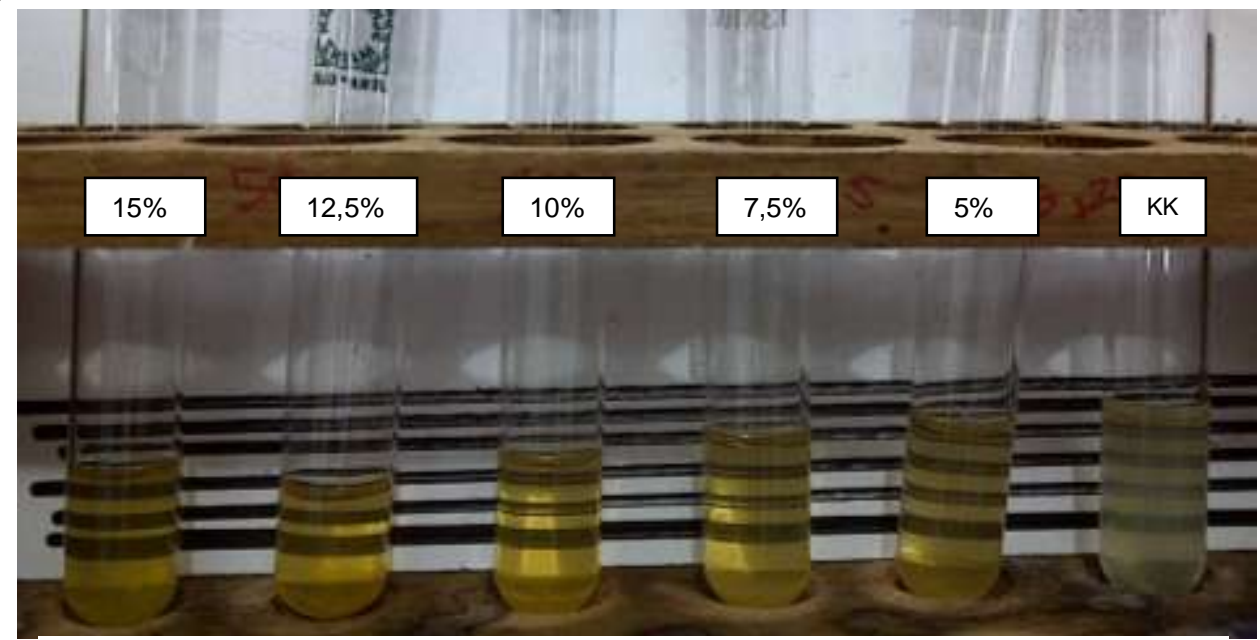

Figure 2. Tube Dilution Result After Incubation note: from left to right $15 \% ; 12,5 \%$; $10 \%$; 7,5\%; $5 \%$; Bacteria Control(KK). In tube of $10 \%$, lines on paper behind tubes are clearly visible

\section{Agar Streaking}

After suspension in tubes were incubated, each of them was streaked on Brain Heart agar plate. Right after streaking procedure was done, agar plates were put into incubator for another 24-48 hours of incubation. 


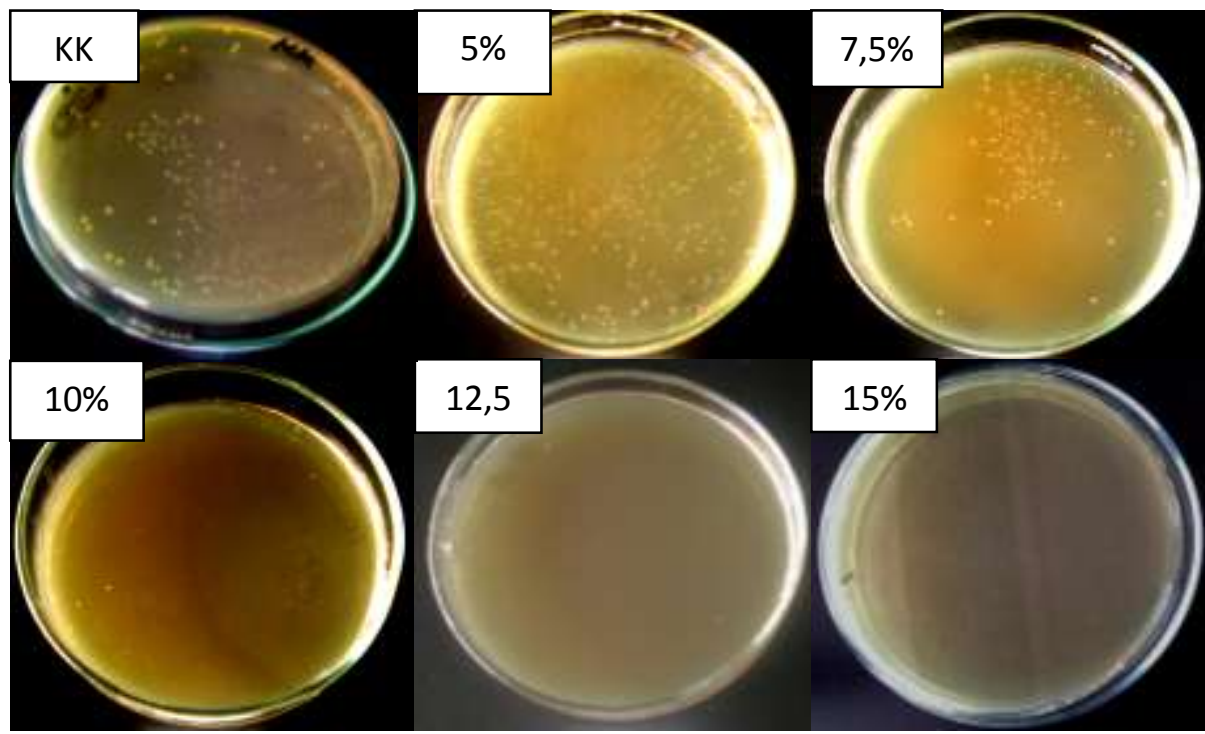

Figure 3. Colonies of Streptococcus mutans on Brain Heart agar plate After Incubation

\section{Statistical Analysis}

Based on SPSS analysis, the Kruskal-Wallis significance result is 0,002. It means different concentrations of white pepper extract shows difference in Streptococcus mutans' count.

Value of significance of Spearman test is 0,00 which shows the correlation between extract concentration and bacteria colony count is significant and worth assess. Value of Spearman correlation is 0,936 . The negative mark shows the correlation is reciprocal between the extract concentration and growth of bacteria colony, where the higher concentration of extract, the lower growth rate of bacteria. The value 0,936 shows the strength of correlation is very strong correlated because it's approaching value of one. This means the white pepper extract has powerful antibacterial effect against Streptococcus mutans.

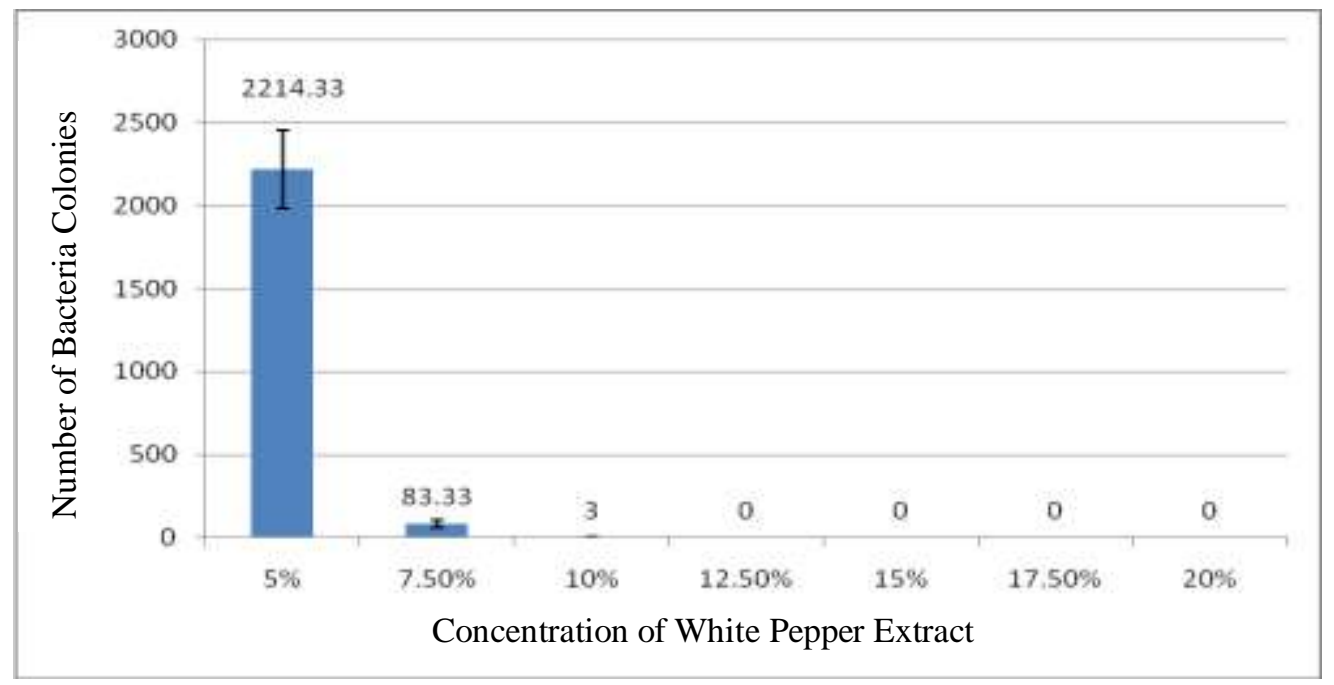

Figure 4. Result of Streptococcus mutans colony counting on Brain Heart agar plate

\section{Discussion}

White pepper extract's ability in inhibiting growth rate of Streptococcus mutans due to its active antimicrobial contents, such as alkaloid, tannin, essential oil, coumarine and phenol ${ }^{9}$. Alkaloid group such as piperine, piperitin, piperidine and chavicine has the properties that obliterate DNA also cell wall synthesis of Streptococcus mutans. Phenol group such as tannin and coumarine work destructively to the bacteria cell wall and interact with DNA. Tannin is a chemical substance in polyphenol group which suspected to bind one of bacterial protein, which is adhesion and if occur it can damage receptor availability on bacterial cell surface. A 
report of in vitro experiment shows there is a significant relationship between biological system (virus, bacteria, and mollusk) and some inhibition enzymes, antioxidant, and anti free radical substances ${ }^{10}$. Essential oil works by damaging bacteria cell wall. The resultant of work of three substances will be able to destroy cell wall and DNA and lead to bacteria lysis.

Identification result by gram staining shows purple (gram positive) because the ability to absorb and preserve the colour of crystal violet given. The morphology of bacteria is coccus stranded chain. Catalase test shows no air bubble appear which prove no reaction occur between the bacteria with hydrogen peroxide as Streptococcus mutans has no catalase enzyme to break down hydrogen and oxygen. If the result of catalase is positive (air bubble is seen), then the bacteria is Staphylococcus. Optochin antibiotic result shows Streptococcus mutans is less sensitive to differ from Streptococcus pneumoniae. Carbohydrate fermentation test shows kinds of fermentable carbohydrate by Streptococcus mutans such as sucrose, rhamnose, and sorbitol. Among those three, especially sucrose is present in daily food so it can be fermented to produce acid that leads to dental caries. Streptococcus mutans is able to ferment higher amount of sucrose compared to other Streptococcus ${ }^{11}$. From the result of the identification tests, can be inferred that the bacteria is proven to be Streptococcus mutans.

There were seven concentration of white pepper extract used in this experiment $5 \% ; 7,5 \% ; 10 \%$; $12,5 \% ; 15 \% ; 17,5 \% ; 20 \%$. These concentrations obtained from several times explorations before experiment is carried out. Method used in the exploration is well diffusion method which shows inhibition zone of white pepper extract against Streptococcus mutans. Serial dilution is then carried out to get exact concentration range to the next exploration until obtaining the final concentrations.

Assessing the MIC was done by assessing minimum concentration of white pepper extract which was able to inhibit the growth of bacteria marked by no blurriness in tube with suspension of Brain Heart Infusion broth and Streptococcus mutans after incubation 18-24 hours. Clearance of suspension was confirmed by observing the lines behind tubes are clearly visible. In this experiment, the suspensions in tube became clearly visible at concentration of $10 \%$. The lines appear to be as clear as substance control and continue staying clear up to concentration of $20 \%$. So it can be concluded the MIC of white pepper extract is $10 \%$.

The MBC of white pepper extract is $12,5 \%$. It's showed by no growth of bacteria colony in this concentration, which is similar as the substance control. This means the MBC was obtained because in concentrations above $12,5 \%$ also no colony of Streptococcus mutans growth in Brain Heart plate.

\section{Conclusion}

1. White pepper extract affects growth rate of Streptococcus mutans in vitro and also prove its antibacterial properties.

2. MIC value of white pepper extract against Streptococcus mutans is at concentration of $10 \%$, while MBC is at concentration of $12,5 \%$.

3. There is a very strong negative correlation between white pepper extract and the growth of Streptococcus mutans. It's proven that the higher concentration of white pepper extract, the lower growth rate of Streptococcus mutans.

\section{Références}

[1] Abdus Salam, M., et al. Establishment of an Animal Model Using Recombinant NOD, B10, D2 Mice to Study Initial Adhesion of Oral Streptococci. Clin. Diagn. Lab. Immunol. 11: 379-386, 2004.

[2] Tanzer, J.M., Livingstone, J., Thompson, A.M. The Microbiology of Primary Dental Caries in Humans. J.Dent. Educ. 2001, 65, 1028-1037

[3] Mayooran, B., Robin S., John, R.T. Dental Caries in Preventable Infectious Disease. Aust. Dent. J. 2000, 45, $235-245$.

[4] Samaranayake, Lakshman. 2007. Essential Microbiology for Dentistry. Philadelphia : Elsevier.

[5] Baum, Lloyd., Phillips, Ralph., Lund, Melvin. 1997. Buku Ajar Ilmu Konservasi Gigi (Textbook of Operative Dentistry). Edisi III. Jakarta : EGC.

[6] Hargono, D.J.1996. Sekelumit Mengenai Obat Nabati dan Sistem Imunitas. Pusat Penelitian dan Pengembangan Farmasi. Badan Penelitian dan Pengembangan Kesehatan.(A Glance of Botanic Drug and Immune System. Health development and research Dept.) Depkes RI. Jakarta. Majalah Cermin Dunia Kedokteran (Journal of Medical World Mirror) no. 108. Jakarta. P. 5-9.

[7] Dorman HJD and Deans SG. 2000. Antimicrobial Agents From Plants: Antibacterial Activity Of Plant Volatile Oils. J.Applied Microbiology, 88(2): 308 .

[8] El-Hamss R, Idaomar M, Alonso-Moraga A, Munos SA. 2003. Antimutagenic Properties of Bell and Black Pepper. Food chem. Toxicol. 41(1): 41-47.

[9] Trivedi, Manisha N., Khemani, Archana, Vachhani, Urmila D., Shah, Charmi P., Santani, D.D. 2011. Pharmacognostic, Phytochemical Analysis and Antimicrobial Activity of Two Piper Species. International Journal of Comprehensive Pharmacy, 7(05).

[10] Agnol, R.Dall, Ferraz, A., Bernardi, A.P., Albring, D., Nor, C., et al. 2003. Antimicrobial Activity of Some Hypericum Species. Brazil: Tanac SA. p 511-516.

[11] Finegold, Sydney, Baron, Ellen. 1986. Bailey and Scott's Diagnostic Microbiology. The C.V. Toronto: Mosby Company.

[12] International Centre for Science and High Technology. 2008. Extraction Technologies for Medicinal and Aromatic Plants. Treste: Italy. p.1 